\title{
An Investigation of Factors Affecting Employee Performance among Millennials in the Public Service in Zimbabwe: A Case of Hospitals in Zvimba District.
}

\author{
${ }^{1}$ Zhakata, L., ${ }^{2}$ Bhebhe, T.B., ${ }^{3}$ Karedza, G. \\ ${ }^{1,2,3}$ Chinhoyi University of Technology
}

\begin{abstract}
This study used mixed research methods to collect data. The survey involved selecting a representative sample of 116 respondents drawn from a population of 701 Millennials (Generation Y employees) working in hospitals in Zvimba District. Questionnaires were administered on 100 Millennials to provide information on factors that affect their performance. Face-to-face interviews were conducted with hospital senior management to complement information provided by the youthful employees and to clarify arising issues.The study established that Generation Y employees prefer to be deployed to hospitals close to their families and friends, where there is internet connectivity, adequate equipment and technology; where transport is readily available and at hospitals which offer accommodation.Millennials in hospitals also expected challenging non-routine work and opportunities for advancement. Issues of decent and fair remuneration, recognition, continuous training and development and positive feedback on contributions were also cited. The study also established that Millennialsprefer democratic, transformational, transactional, consultative/participatory and servant leadership and will not perform well if managers used autocratic leadership styles. The study recommended leadership training to help managers of Millennials in the health sector to appreciate the needs of these young employees.Noting that most leaders and managers of Millennialsare older generation (Generation X), the study recommended health leaders and managers to develop complementary set of leadership and motivationalcapabilities through leadership development, succession planning, collaboration, knowledge sharing,delegation, training and development,. Concerted effort should be made to deal with issues of remuneration so that young health employees love and respect their work. Key words: Millennials, Generation Y, Generation X, health worker, employee performance.
\end{abstract}

\section{Introduction}

In this study, the words Millennials and Generation Y were used interchangeably to mean the same. The words refer to youthful employees in the workplace born between 1981 and 1994. Press reports have been awash with cases of laziness, lack of commitment, shouting at clients, late reporting for duty, negligence and other undesirable actions which border on 'I don't care' attitudes among youthfulhealth employees. There was also a worrying phenomenon of high staff turnover from this cohort with most migrating to other countries in search for greener pastures.It was also noted that those who chose not to migrate were not providing services according to standards, and not being responsive to the needs of the communities and patients (Dieleman and Harnmeijer, 2006). This is contrary to reality that these youthful employees willingly spent years of training to pass and they applied and joined a profession which they now do not seem to enjoy. This paradox is what motivated the study and hospitals were viewed as most affected. The study aimed at investigating factors affecting the performance among the young generation of health workers who are generally referred to as Millennials or Generation Y. At the time of the study in 2017, this cohort of workers were aged between 22 and 36 years.

\subsection{Background to the study}

The notion of generations is widely used in everyday language to denote differences between age groups in society and to locate individuals within historical times; for instance, Baby Boomers are a generation born between 1946 to 1962 after the Second World War when there was a sudden increase in the number babies born in most countries especially in America (Mishler and Richard 2005).

In order to respond to the general outcry among members of the public that attitudes and work ethics of the young generation of health workers left a lot to be desired, there was need to carryout research to find out why young employees seemed not to enjoy their work. The study sought to understand the characteristics and needs of the young generation of workers in order to proffer suggestions which would helpaddress the situation because patients who are their major clients cannot continue to suffer from negligence and poor service delivery.A lot of research has been carried out on the expectations and needs of Generation $\mathrm{Y}$ in developed countries. However, given that different countries have different environments, cultures and levels of development, what is said about Generation Y in Country Amay not necessarily apply in Country B. What 
motivates or demotivates Generation Y workersin Country A may not apply to Country B. This study aimed at generating new knowledge on what affects the performance of Millennials in the Zimbabwean context. Many scholars among them Mishler and Richard (2005),Kian (2012), Kranenberg (2014), Spiro (2006) and McCrindle (2002) researched about generational cohorts as they apply in developed countries and the figure below helps to illustrate what the earlier scholars agreed as the generational age groupsin the international context:

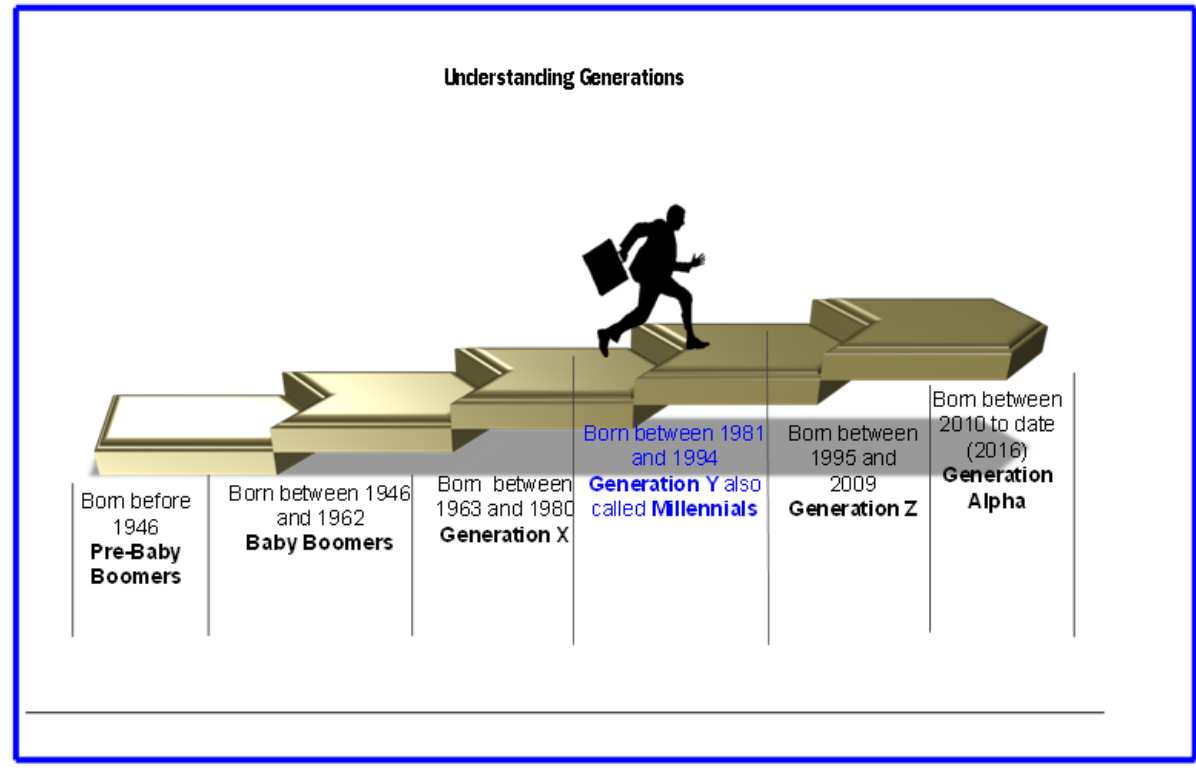

Source: Author, 2017

By the beginning of 2017, most of the working agegroups fell within three cohorts:Baby Boomers who are aged between 54 and 70 years with some nearing retirement or retired; Generation X (aged between 36 and 53 years) and Generation Y or Millennials(aged between 22 and 36 years). However, there are outliers who are still in employment among the Pre-Baby Boomers (those above 70 years) while some in Generation $\mathrm{Z}$ (those below 22 years of age) may also be found in the workforce in some sectors. A point to note is the slight overlap in years as presented by different scholars and researchers. Howe and Strauss (2000) as quoted in Leavitt (2014) point out that the actual periods of birth vary from researcher to researcher. This should be expected and accepted as normal given that there are no strict hard-lines or cut-off birth years to denote generational cohorts; they are marked only by common career expectations, common behaviours, work habits, life goals and attitudes shaped largely by the social and historical eras in which they came of age. Managersshould endeavor to understand generational differences of their workers inorder to enhance work performance, retain the best talent and to ensure that tensions that are bound to arise at work places do not interfere with the smooth running of organizations.

\subsection{Statement of the Problem}

A lot of research has been carried out in developing countries on the expectations and needs of Generation Y after it became apparent that their work culture, career expectations, work habits and work ethics are markedly different from the other generations before them. It also became clear that the needs and expectations of the Generation Y cohort might differ from country to country. Managers and supervisors of Generation $\mathrm{Y}$ employees need to be advised by researchers so that they can get the best out of this young generation of workers. The out-migration of health practitioners to countries in the region or overseas remains one of Zimbabwe's most pressing problems (Chimbari et al, 2008). Generation Y also known as the mobile generation, are leaving employment in large numbers leaving hospitals with critical staff shortages as Baby Boomers retire. There was need to investigate the career needs and expectations of Generation Y employees to understand what they value in order to retain them and motivate them to work hard and enjoy their chosen careers. The high turnover rate is costing hospitals huge amounts of money every year. The big question is: How can managers in Zimbabwe manage and incentivize Generation Y?This study soughtto identify factors influencing the performance of Generation $\mathrm{Y}$ and to draw insights to policy-makers and practitioners on ways to enhance the performance of Generation Y. 
An Investigation of Factors Affecting Employee Performance among Millennials in the Public...

\subsection{Research objectives}

This study sought to:

1. identify factors influencing the performance of Generation $\mathrm{Y}$ in Zimbabwean hospitals.

2. identify leadership styles which are appropriate for Generation $\mathrm{Y}$ in Zimbabwe.

3. Identifythings that motivate Generation $\mathrm{Y}$ employees to be high performers in hospitals.

4. recommend strategies that can be adopted to improve the performance and commitment of Generation $Y$ employees in order to nature talent.

\subsection{Hypothesis}

$\mathbf{H}_{\mathbf{0}}$ : The performance of Generation $\mathrm{Y}$ in Zimbabwe is not significantly associated with leadership style used by their managers.

$\mathbf{H}_{\mathbf{1}}$ : The performance of Generation Y in Zimbabwe is significantly associated with leadership styleused by their managers.

\section{Literature Review}

Tayler and Procter (2010) stated that not only should relevant writings be reviewed but they also ought to be analysed critically to find room for development through identifying areas for further investigation bycomparing facts.

\subsection{The Concept of Generations}

Kupperschmidt in Kian (2012) defined a generation as people that are grouped within a certain range of ages and significant life events they experienced at critical development stages. McCrindle (2002) as supported byKranenberg (2014) states that there are three aspects that define a generation: age, conditions and experience. Spiro (2006) postulates that a generation is shaped by its history and that this works through to the workforce. Employees from different generations have different experiences, work habits, work ethics, values, goals andcareer expectations potentially causing difficulty as they work side by side (Kogan, 2001). A generation is established by set of values, orientation to the world, loyalty, what they expect from their leadership and the ideal environment.

According to Macky et.al (2008) as cited in Leavitt (2014), generational differences occur as a result of significant influences in the environment during a cohort's early development and socialisation which impact the development of personalities, values and beliefs that remain stable into adulthood. Huybers (2011) defines a generation as a group of people sharing a particular statistical or demographic characteristic, born in the same general time span, who share key life expectations. Generations are shaped more by history than by chronological dates argues Reeves and Oh (2007).

\subsection{General characteristics ofgenerations found in the current work place}

Many scholars and researchers among them Kogan (2001), Mishler and Richard (2005),Kian (2012), McCrindle (2002), Kranenberg (2014) and Spiro (2006) attempted to identify the general characteristics of workers. Figure 2 below summarisesthe findings of these earlier researchers and scholars on the common characteristics which identify each generation:

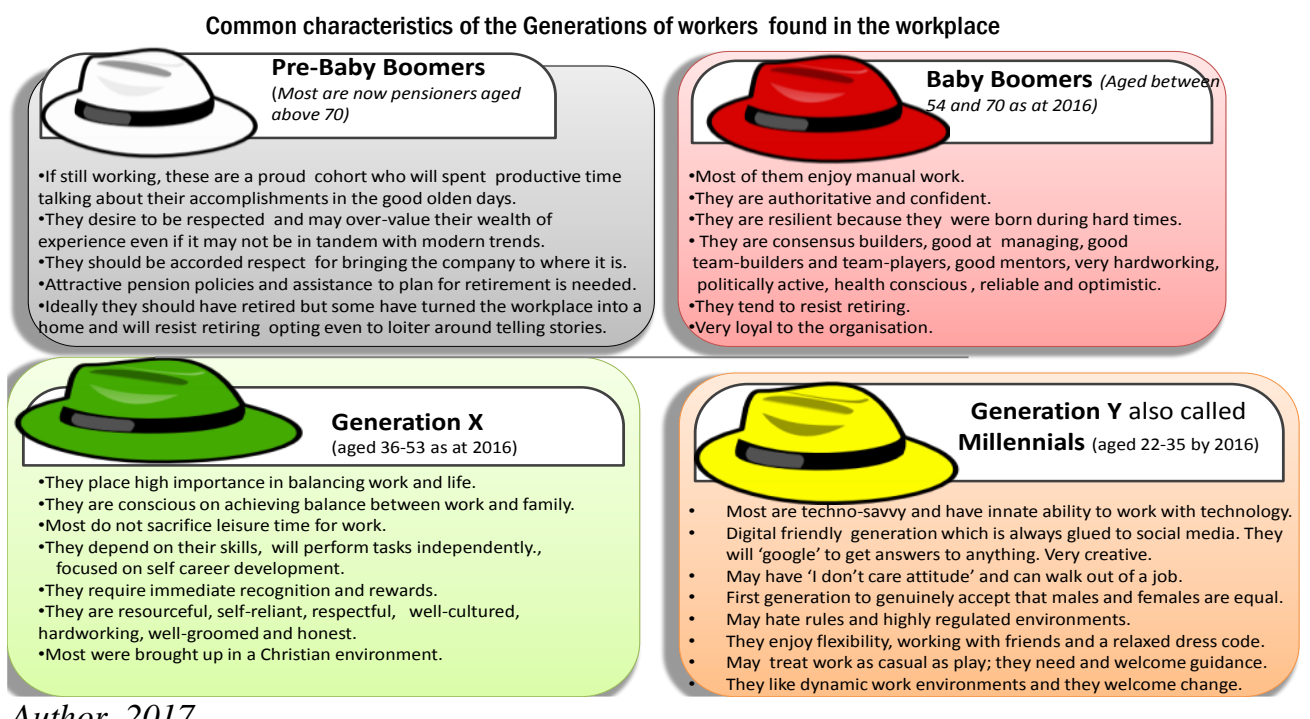

Source: Author, 2017 
The above summary shows that today's workforce is more diverse than at any other time in history and for that reason the 'one size fits all' motivation policies and leadership styles at work places may not always work. This calls for versatile managers who have invested in understanding their workforce in order to nurture talent. Failure to understand generational gaps among employees can lead to conflict and other related problems at work which can stall production. Individual differences should not be ignored.

\subsection{A Case for Millennials (Generation Y)}

Two authors, William Strauss and Neil Howe are widely credited for giving the name 'Millennials'and coining the word in 1987. Usage of the word 'Generation $\mathrm{Y}^{\prime}$ came later in 1993. Since this study is about Millennials or Generation Y, further to the above Figure which summarises characteristics of different generations, this section is devoted to bringing out more detail about the findings of earlier researchers concerningMillennials.

Douglas McGregor in his book, 'The Human Side of the Enterprise' (1960) in what he termed Theory $\mathrm{Y}$, noted thatthere is no worker who is lazy without cause because workers can be made to naturally enjoy working hard as if they are playing or resting yet they will be sweating to achieve organisational goals. This calls for managers with extra-ordinary people management skills. Once managers seek to understand Millennials, they will not label them as lazy or uncaring. As at 2017, Generation Y (Millennials) can be understood as recent graduates from college or university and that makes them genuinely full of knowledge but empty on experience. The fact that their knowledge may not suite a particular workplace, machinery or system does not mean they have no knowledge. They know what they know and they should be respected for that. Clever managers tap into this knowledge, intelligence, zeal, innate ICT skills and positive energy and redirect these towards the desired outcomes because as stated earlier, Millennials are now in majority in most workplaces. There is no company or organisation which can afford to ignore them.

Kranenberg (2014) notes that Generation Y were born into an emerging world of technology and have grown up surrounded by smart phones, iPhones, laptops, tablets and other gadgets. They enjoy being constantly plugged into technology and it becomes an essential aspect of this generation's life. Deploying them in a remote hospital which has no wi-fi/ internet connectivity may create a dislike for work which may have far-reaching consequences on their treatment of clients. Rather than force them into remote hospitals, authorities should strive to improve the remote hospitals by connecting internet, electricity and other such facilities which make Millennials feel at home; bearing in mind that it may not be fair to blame them because it is not them who chose to be born during the technology era. Technology is what they grew to know right up to employment and it should be viewed as impossible or futile to try and change or separate them from it. They willdislike working where there is no semblance of technology. Whether one may love or hate Millennials, this is the generation to bank on for any business which will last into the future because they are here to stay, and they will continue to make inroads within business. Businesses/ companies can ignore them at their own peril because they are entering the labour market in large numbers and they are an influential group.

Miller, Hodge \& Brandt (2013) cited in Jerome et.al. (2014) state that Generation Y are a digital generation who desire to access social media and electronic devices while at work in order to remain happy and produce results. Ibid (2014) went further to state that Millennialsseek flexibility, relaxed dress codes, and the use of social media and personal computing as necessary components to employment. Generation $\mathrm{Y}$ will prefer quick communication usually through e-mails, Facebook, Twitter,Whatsapp social media platform or any such platforms as opposed to the traditional methods. Asking them to write and send a hard copy letter will be asking too much and no matter how easy that is, they will find it to be a mammoth task. If one requires instant response from this generation, one should send an e-mail, a tweet or Facebook message or any platform which is in Generation Y terms not a copy of a letter or a memo.

Most of the Millennials grew up with over-protection from parents. For that reason, family life takesprecedence. No matter how joyful the workplace might be, to them family comes first. They will be the happiest travelling home from work butthat does not mean they do not like work. Although they may have been over-protected, most grew up with over-worked parents. As Millennials grew to seetheir parents 'toiling', coming home late from work, exhausted, in dirty overalls but claiming to have insufficient money; this created in Millennialsa negative feeling about workplaces.Owing to this background, Millennialscan easily think that a workplace is a place where people are exploited and overworked for little pay, thus any delegation of tasks beyond normal working hours needs to be done strategically. Twenge (2006) called them the 'Me MeMe Generation' because they can be selfish and happy on their iPhone,pluggingear-phones whole day and that does not mean they are not working hard. Millennialstend to take a casual approach to work and they need guidance from management and older employees (Gursoy et.al, 2008). Millennials at workplaces enjoy working in teams and they want to be involved and included. They dislike being ignored because they grew up with full attention from parents and older siblings. More interestingly, they are very confident and can gun for any role or post in the workplace notwithstanding their lack of experience. Most Millennials believe that there is no limit to what 
they can achieve. This attribute is good for innovative work environments. They prefer a flat corporate culture and they dislike bureaucracy.If their ambitions are not met, they find it easy and natural to leave and find a 'better' job or even stay at home. They prefer a creative outlet, close friendships with supervisors and immediate feedback. Since most grew up under parental protection, they therefore want to be loved at work, otherwise they leave.

An exciting characteristic is that Millennials have a trend for sport. They find a workplace without sports as boring. Good employers tap into this attribute by forming sports teams and setting aside at least an afternoon or an hour for sports in a week. Alsop (2008) called Millennials the 'Trophy Kids' because of their crave for competitive sport. Millennialsvalue rights and equality and will dislike any manager or politician who is racial, gender biased or who uses divide and rule tactics. To them, all human beings are equal and must be equal.This notion is supported by Lancaster and Still in Denham (2002) who argue that after all, Millennials have travelled around the world 'on internet' and they consider themselves as international citizens in a global village unlike the older generations who may have grown up knowing only their rural village. This attribute makes Millennialssmart, practical and appreciative of diversity. They are more open-minded than any other generation. Historical talk about oppression and discrimination does not impress them. Orrell (2007) as supported by Huybers (2011) add that this is the first generation of boys to be raised to respect girls as equals and also the first generation of girls raised to believe that they are equal to boys. This can be noticed by their proximity when sitting, their attire or their language when both sexes are together. Millennial boys associate and sit very close to girls and vice versa; they hug and kiss easily as a way of greeting yet other generations before them may be uncomfortable to do so in public.That same attitude transcend the racial divide which they view as non-existent. They believe they are equal to any race, an attribute which can make them work well in teams which have a racial mix. Shaw andFairhurst (2008) noted that Millennials are a very motivated cohort which is ambitious and entrepreneurial.

Dorsey (2010) as cited in Huybers (2011) postulates that although most Generation Y employees are loyal, they are only loyal if they are treated well. They are not likely to suffer in silence if they are nottreated well or are not appreciated and rewarded appropriately unlike their predecessors Generation X and Baby Boomers.Erickson (2008) states that social issues such as working mothers, increased gender equality and prochild culture affected the behaviour of Millennials. The continued reinforcement and praises Millennials received from their parents early in life has translated into adulthood to what some view as optimism, but others consider it to be false self-confidence and sense of entitlement. If transferred to the workplace, this sense of entitlement means this generation expects to climb the career ladder at a rate considered to be unreasonable by co-workers from other generations (Karefalk, Petterssen\& Zhu, 2007).Cruz (2007),Feliz, (2007) and Denham (2002) concur that when Millennials expectations are not met, they easily leave and move on to new opportunities where they will be more appreciated.

Fenn (2010) states that Millennialswelcomechange more easily because change creates a dynamic work environment that is perceived as exciting. Ibid (2010) went further to state that Millennials dislike routine. They want work which is constantly challenging, recognition seamless and coupled with immediate feedback. This generation believes in teamwork and prefers to follow directions as long as there is room for flexibility. Howe and Strauss (2000) in Reeves and Oh (2007) state that Generation Y are more affluent, better educated and more ethnically diverse than the other generations and more importantly, are beginning to manifest a wide array of positive social habits than older generations. They no longer associate with youth including a new focus on teamwork, achievement, modesty, and good conduct. Reeves and Oh (2007) further postulate that the work habits of Millennialsmake themeasily adapt to multitasking using a diverse range of digital media, and literally demand interactivity as they construct knowledge. On the other hand Millennials lack the workaholic attitude of their predecessors, but compensate this by using many technologies often simultaneously to get the job done quickly and simplerin order to complete the task and attend to personal life. Denham (2002) stated that Millennials rank personal safety as their number one workplace issue. Rollin (1999), Collins (2000), Howe \& Strauss (2000) and Denham (2002) agree that Millennials are team oriented, optimistic, practical,they trust authority and traditional institutions. According to Denham (2002), as compared to Generation X, Millennialsadmire and embrace the value of their elders more. They are a perfect group to become consultants and entrepreneurs. Millennials desire personal attention from those in charge and want to know if their efforts are recognized and valued. Dols et.al (2010) in Leavitt (2014) went further to state that Millennials are disillusioned if fairness is missing or devalued at a workplace.

Kamau et.al (2014) postulated that employers need to seek greater understanding and more ideas relating to hiring and retaining Millennials. This is because it is evident that Millennials have a different attitude towards work as compared to previous generations. They do not live to work, they work to live. Older employees may think that they are arrogant.If work is not exciting, Millennials may not respect authority, they register high rate of absenteeism, frequently reporting late for duty and have high rate of changing jobs. 
Hospitals where Millennials work need to understand the above case in order to be able to nurture talent, tap into the strengths and positive attributes of this generation. Understanding Millennials will help managers to turn the workplace into an exciting and motivating place.

\section{Methodology}

The survey strategy was employed for this study. It involved selecting a representative sample of Millennials from hospitals in Zvimba District. Quantitative and qualitative data collected through selfcompleting questionnaires and face-to-face interviews was presented andanalysed. According to Greener (2008) and Saunders, Lewis and Thornhill (2009) combining quantitative and qualitative strands offsets their weaknesses drawing on the strengths of both approaches by answering different research questions with one approach and explaining findings generated by the other. Thisenhances the integrity of research findings.

\subsection{The Population and sample}

The population under study comprised 701 Millennials who work in hospitals in ZvimbaDistrict. The data was generated from schedules supplied by Hospital administrators which showed names, dates of birth, gender and other details. Seven hospital managers were interviewees who explained and validated certain information collected from Millennialsrespondents. This was done to gain in-depth understanding and to allow for triangulation.

Out of a population of 701, using the Raosoft sample size calculator at $95 \%$ confidence level and $5 \%$ margin of error and a presumed response rate of $90 \%$, the resultant sample size of 116 was computed (http://www.raosoft.com/samplesize.html).Lists of Millennialemployeesin each hospital in Zvimba District were drawn. A random sample was selected from each hospital list using computer generated random numbers yielding an unbiased representative sample of the population. Hospital managers were selected conveniently to complement information provided by Millennialsrespondents.

\subsection{Data collection instruments}

Questionnaires and unstructured interview guides were used to collect data from among the respondents. There was need to ensure that the main data collection tool, the questionnaire, was valid and reliable. This section presents the validity, reliability and normality tests of the constructs used in the research.Fifteen subjects comprising young health service employees from outside the study area in Chinhoyiwere used for pre-testing/pilot testing. They made comments on the simplicity and clarity of questions and that the appearance and layout was excellent. Construct validity was tested using principal component analysis and factor analysis. The Table below shows the first principal component analysis run.

\subsubsection{Principal Component Analysis}

\begin{tabular}{|l|l|l|l|l|l|l|}
\hline \multirow{2}{*}{ Component } & \multicolumn{2}{|l|}{ Initial Eigen values } & \multicolumn{3}{l|}{ Extraction Sums of Squared Loadings } \\
\cline { 2 - 7 } & Total & \% of Variance & Cumulative \% & Total & \% of Variance & Cumulative \% \\
\hline 1 & 8.323 & 21.341 & 21.341 & 8.323 & 21.341 & 21.341 \\
\hline 2 & 4.959 & 12.714 & 34.056 & 4.959 & 12.714 & 34.056 \\
\hline 3 & 2.509 & 6.435 & 40.490 & 2.509 & 6.435 & 40.490 \\
\hline 4 & 2.253 & 5.777 & 46.268 & 2.253 & 5.777 & 46.268 \\
\hline 5 & 1.846 & 4.733 & 51.001 & 1.846 & 4.733 & 51.001 \\
\hline 6 & 1.720 & 4.410 & 55.411 & 1.720 & 4.410 & 55.411 \\
\hline 7 & 1.649 & 4.228 & 59.639 & 1.649 & 4.228 & 59.639 \\
\hline 8 & 1.309 & 3.356 & 62.996 & 1.309 & 3.356 & 62.996 \\
\hline 9 & 1.190 & 3.050 & 66.046 & 1.190 & 3.050 & 66.046 \\
\hline 10 & 1.157 & 2.968 & 69.014 & 1.157 & 2.968 & 69.014 \\
\hline 11 & 1.056 & 2.707 & 71.721 & 1.056 & 2.707 & 71.721 \\
\hline 12 & 1.036 & 2.658 & 74.378 & 1.036 & 2.658 & 74.378 \\
\hline 13 & .887 & 2.275 & 76.653 & & & \\
\hline
\end{tabular}

Source: SPSS output

The table above shows results of the first run of Principal Component Analysis (PCA). It can be seen that the total variance of the draft questionnaire factors was $74.4 \%$, implying that more than $70 \%$ of the variance could be explained by common factors. This is considered reasonable by Field(2005) as cited in Chanaka (2015). The communalities of the items on the questionnaire were greater than 0.5. On applying Kaiser's criterion to the draft questionnaire, 12 factors had Eigen values greater or equal to 1.00 in the first PCA run. A 12 factor solution with varimax rotation was deemed to be the most statistically and conceptually appropriate to the questionnaire. In undertaking the most appropriate interpretation, the loading values were examined leaning on Hair, Anderson, Tatham\& Black's (1998) guideline in Chinhamo(2015) for practical significance, which indicated that a factor loading of \pm 0.3 means the item is of minimal significance, \pm 0.4 indicates it is more important, and \pm 0.5 indicates the factor is significant. All items were retained in the factor pattern matrix of the

DOI: 10.9790/5933-08010390108 www.iosrjournals.org 95|Page


questionnaire since the factor loadings were greater than \pm 0.4 .

\subsubsection{Scree Plot}

As part of the PCA, the scree plot below also aided to approve the questionnaire as a valid tool.

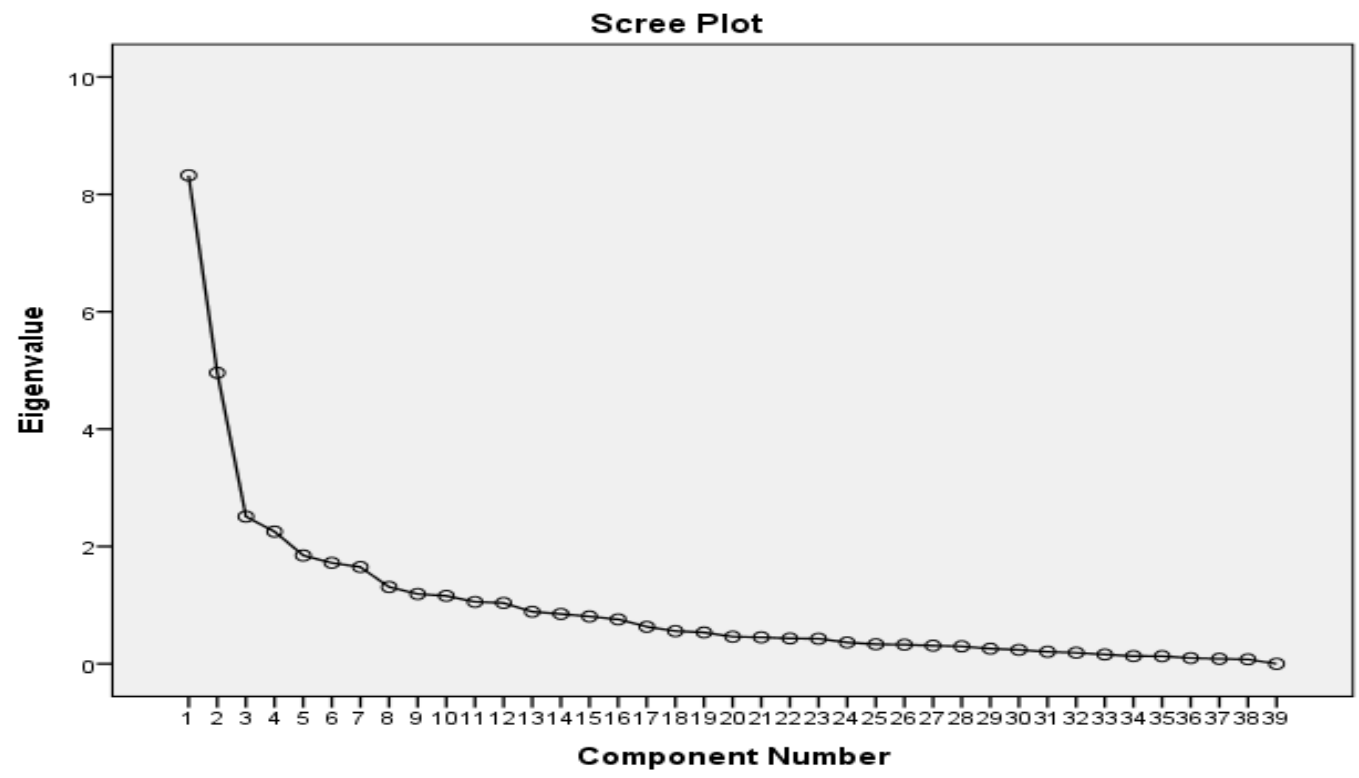

Source: SPSS Output

As indicated on the scree plot above, the eigenvalues associated with the component or factors are in descending order versus the number of the component or factor. The use of the scree plot in computing principal components analysis and factor analysis helped to come up with face validity where it was visually possible to assess which components or factors explain most of the variability in the data with the eigenvalues on the $\mathrm{Y}$-axis and the number of factors on the $\mathrm{X}$-axis showing a downward curve to prove validity.

\subsubsection{Reliability}

The alphas for all constructs in the questionnaire and the global alpha table below were greater than 0.7, implying that the questionnaire used in the study was internally consistent and reliable. It can be concluded that the results of the study can be replicated under similar conditions.

Table showing the global alpha.

\begin{tabular}{|l|l|}
\hline \multicolumn{2}{|l|}{} \\
\hline Cronbach's Alpha & No. of Items \\
\hline .813 & 39 \\
\hline
\end{tabular}

\subsubsection{Normality Test}

The Normality Test showed results for the Shapiro-Wilks tests. All p-values were 0.000 showing that the data was not normally distributed, hence the use of non-parametric tests.

\subsection{Response Rate}

Out of a sample of 116, 100 respondents managed to complete and return the questionnaires and that constituted 86\%. Authorities of research such as Babbie (2001), Bell and Bryman (2003) and Brannick and Roche (2011) accept such a response rate as a high when they state that any response rate of 50\% and above is good enough. 


\section{Findings}

4.1 Socio-demographic characteristics of respondents

The Table below shows the socio-demographic characteristics of Millennials who participated in this study.

\begin{tabular}{|c|c|c|}
\hline Characteristic & & $\begin{array}{l}\% \text { Frequency out of } 100 \text { completed } \\
\text { and returned questionnaires }\end{array}$ \\
\hline A1. Gender & Male & 43 \\
\hline & Female & 57 \\
\hline A2. Age group & $22-28$ years & 36 \\
\hline & 29-35 years & 64 \\
\hline A3. Job Title & Doctors & 3 \\
\hline & Nurses & 42 \\
\hline & Administrative & 13 \\
\hline & Paramedics & 20 \\
\hline & Other & 22 \\
\hline A4. Education Level & Primary & 0 \\
\hline & Secondary & 24 \\
\hline & Tertiary & 76 \\
\hline A5. Experience & Less than one year & 2 \\
\hline & $1-3$ years & 19 \\
\hline & Above three years & 79 \\
\hline A6. Computer Literate & Yes & 78 \\
\hline & No & 22 \\
\hline A7. Intention to Leave Organization & Yes & 66 \\
\hline & No & 34 \\
\hline A8. Self-Assessment on Performance & Excellent & 35 \\
\hline & Very Good & 32 \\
\hline & Good & 33 \\
\hline & Poor & 0 \\
\hline & Very Poor & 0 \\
\hline A9. Self-Assessment on Attitude towards Work & Very Positive & 44 \\
\hline & Positive & 45 \\
\hline & Negative & 10 \\
\hline & Very Negative & 1 \\
\hline
\end{tabular}

Source (Author, 2017)

\subsubsection{Gender}

Computations as shown on the above table show that $43 \%$ of the respondents were male and $57 \%$ were female. Orrell in Huybers (2011) carried out a study and concluded thatMillennialsis the first generation to treat boys and girls as equal. Although females constitute a greater percentage of respondents, this would have minimal effects since they treat themselves as equal to males. The percentages reflect the true situation on the ground in most hospitals in Zimbabwe. This is often attributedtotraditional stereotypes which treated nursing as motherly care of patients as such nursingis traditionally believed to be more suitedto women. Traditional literature in schools which glorified Florence Nightingale as the 'Mother of Nursing' did not help the situation as it helped entrencha belief among school children who are now Millennials that nursing is more suitable for girls. In Zimbabwe,the health profession is still staffed by more females than males, a situation which is slowly changing.

\subsubsection{Age}

Figure 4.2Age

Source (Author 2017)

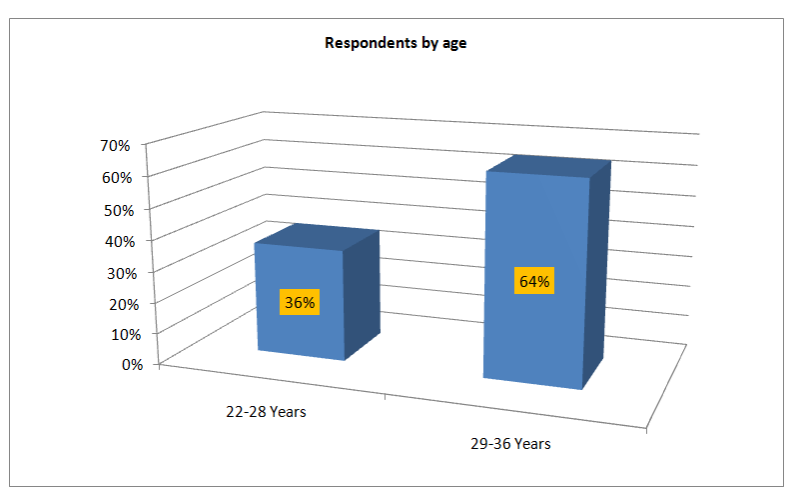


The table above shows an analysis of the ages of respondents. The table shows that hospitals in Zvimba District are employing young Millennials as shown by $36 \%$ of the respondents who were between the ages of 22 and 28years. Such respondents are likely to be fresh from college or university and have little or no experience. The table also shows that $64 \%$ were Millennialsbetween the ages of 29-36years. This greater percentage comprises matureMillennialswho possess few years of work experience after graduating from college or university.

\subsubsection{Job Title}

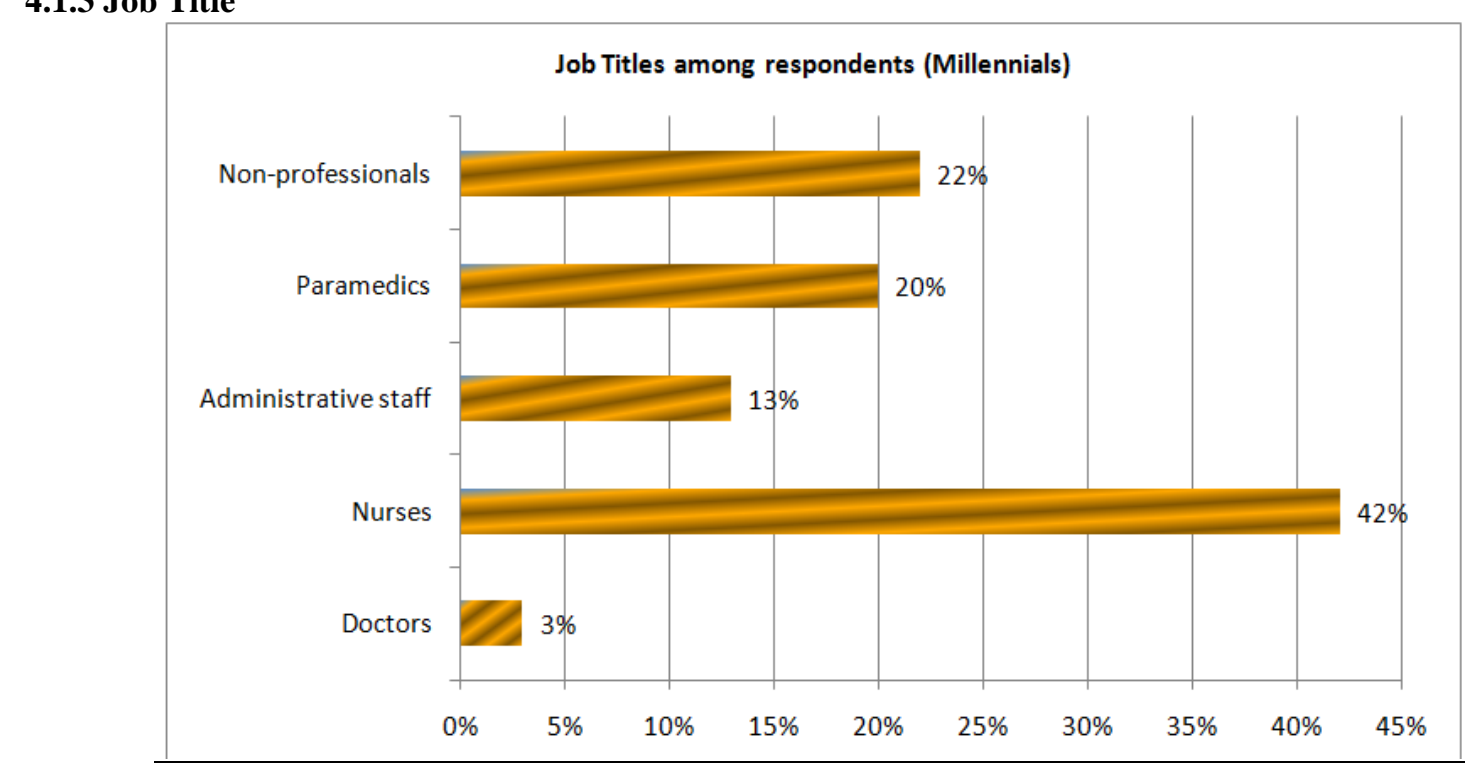

\section{Source (Author 2017)}

Of the 100 respondents,doctors represented $3 \%$, nurses $42 \%$, administrative staff $13 \%$, paramedics $20 \%$ and non-professionals $22 \%$ as depicted by the figure above. Sixty-five percent of the respondents were from the clinical area (nurses, doctors and paramedics) and 35\% were from the administrative departments comprising administrative staff and non-professionals. All staff categories were represented thus increasing the validity and reliability of the research findings.

4.1.4 Level of educational attainment

\section{Source (Author 2017)}

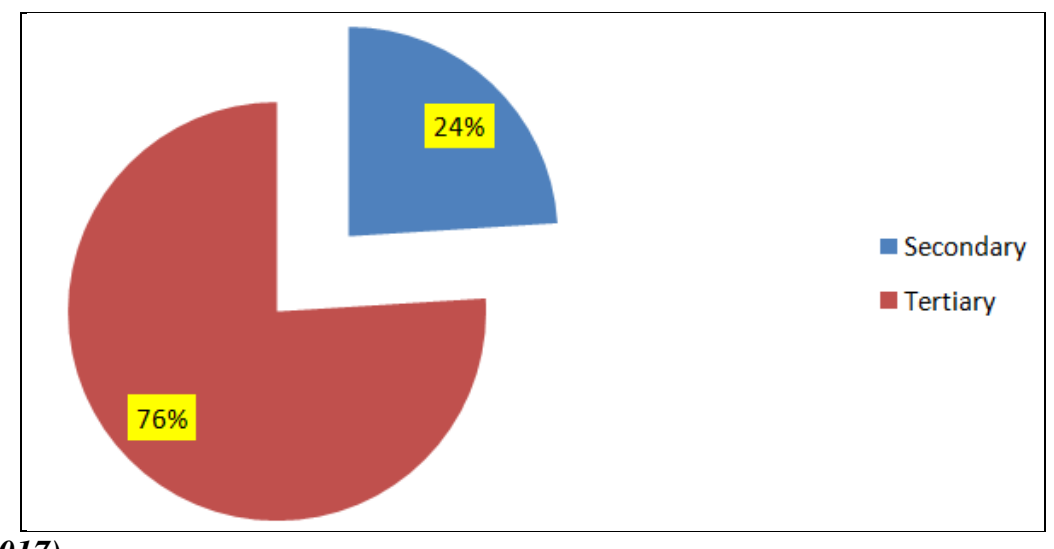

Out ofthe 100 respondents, $76 \%$ attained tertiary education (college diplomas, certificates and degrees) while $24 \%$ attained secondary school certificates. Given that the set minimum qualifications for clinical staff is a certificate or diploma for nurses and paramedics and a degree in Medicine for doctors, it can therefore be agreed that all the $65 \%$ who make up clinical staff and a few administrative staff make up the $76 \%$ who attained tertiary qualifications. 


\subsubsection{Work Experience}

\section{Source (Author 2017)}

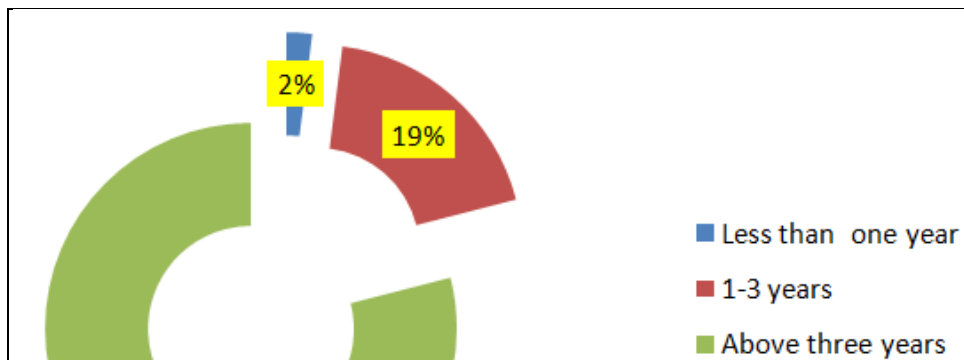

The Figure above indicates that $79 \%$ of the respondents were in service for more than three years, $19 \%$ had between 1-3years of experience and only $2 \%$ had less than one year of service. Such a profile with $79 \%$ of the Millennialshaving served for more than three years is quite good. Such employees are now expected to have the zeal to excel in a profession they chose. While those who had served for less than three years are in the minority, such Millennials need more guidance and mentoring for them to acquire practical skills of the job. They are not expected to excel as they are still new in the profession.

\subsubsection{Computer Literacy}

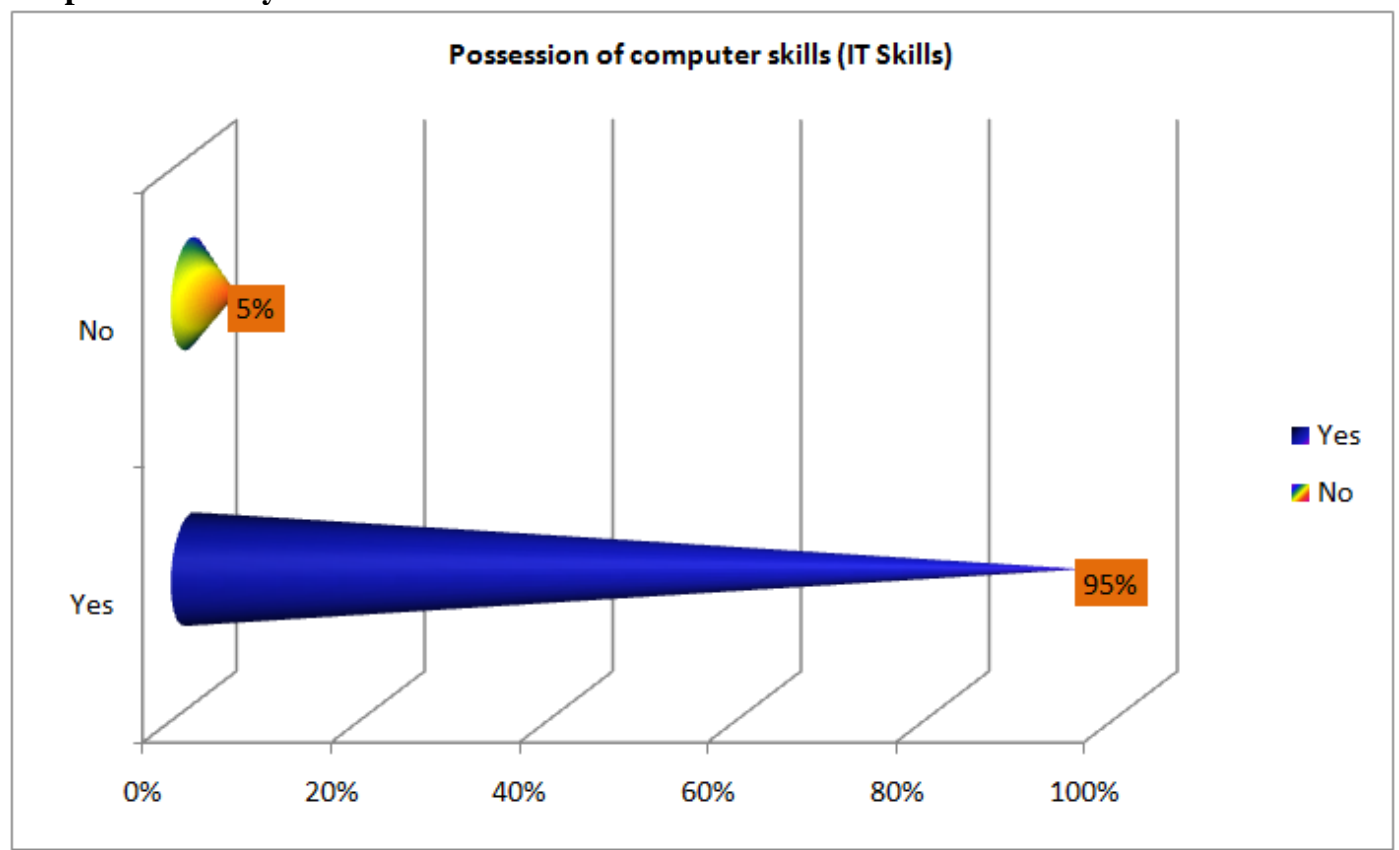

Source (Author, 2017)

The Figure above shows that $95 \%$ of the respondents were computer literate by the time of the study and only5\% were not.This agrees with the findings of previous studies by Lancaster and Still, in Denham, (2002) who said that Millennialsare smart, practical, appreciative of diversity and techno-savvy individuals, having travelled the world 'on internet'. The study conducted by Miller, et.al (2013) found out that Generation Y are a digital generation and accessing social media and electronic devices while at work is in order if they are to remain happy and produce results. However, research by Reeves and Oh (2007) noted that Millennials lack the workaholic attitude of their predecessors, but compensate by using many technologies often simultaneously to get the job done. Contrary, this does not always apply in thehealth delivery service in hospital setups because patients may not require technology in order to be healed but good care and medication. This creates conflict situations forMillennials who may find that hospitals are not Millennial-friendly with wards and hospital beds that are not technology intensive but have sick patients needing care. If the findings of cited scholars and 
researchers are anything to go by, it is such a work environment which is devoid of technology which causes Millennials in hospitals to feel bored and eager to leave.

\subsubsection{Intention to leave the Organisation}

There was need to find out if Millennials serving in hospitals haboured intentions to leave the hospital:

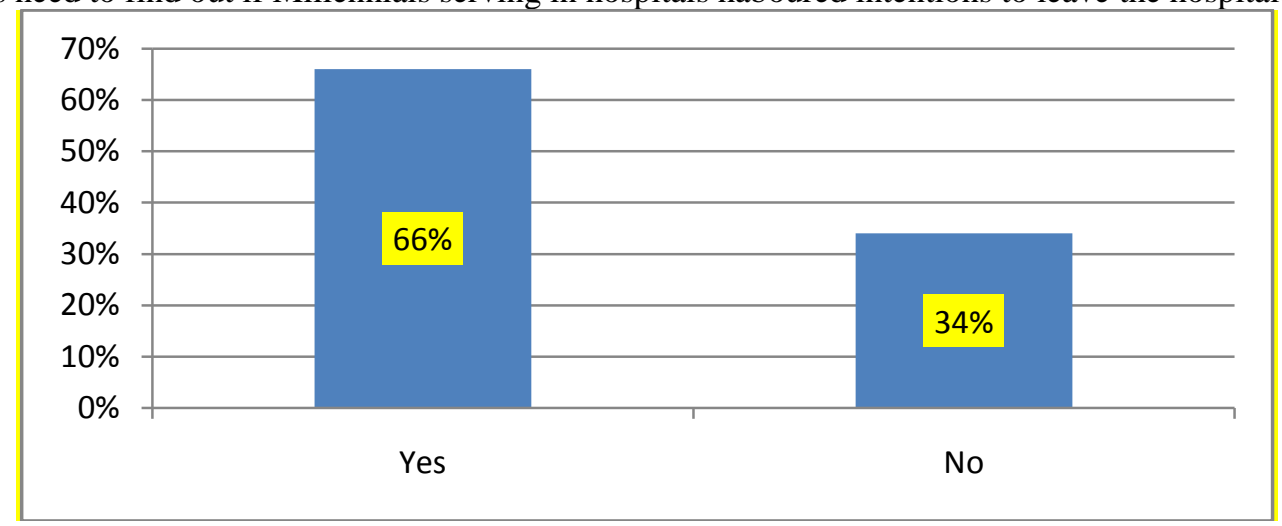

\section{Source (Author, 2017)}

The figure above indicates that66 out of 100(66\%) of the respondents stated that they were eager to leave the organisation if opportunities arose and only34\% stated that they wanted to remain in the hospitals. These results concur with Cruz (2007), Feliz (2007) and Denham (2002) who pointed out that when Millennials expectations are not met, they show willingness to move on to new opportunities where they perceive they will be more appreciated. However, given the economic situation in Zimbabwe where industry capacity utilization is around 30\% with most industries having closed down and also given that according to press reports, neighbouring countries Botswana and South Africa are deporting Zimbabwean immigrants in large numbers, Millennials in hospitals whohabour interests to resign may remain in hospitals for longer. According to Kamau et.al (2014) Generation Y have a high rate of changing jobs and employees who are waiting for the earliest opportunity to leave anorganisation are known not to exert effort in their jobs and patients are bound to suffer from poor service delivery.

\subsubsection{Employee Performance}

There was need for respondents to rate their performance and emphasis was given that they should be as honest as possible, taking into consideration the appraisal comments from their supervisors before rating themselves as Excellent, Very Good, Good, Below Average or Poor. The results are as illustrated on the table below:

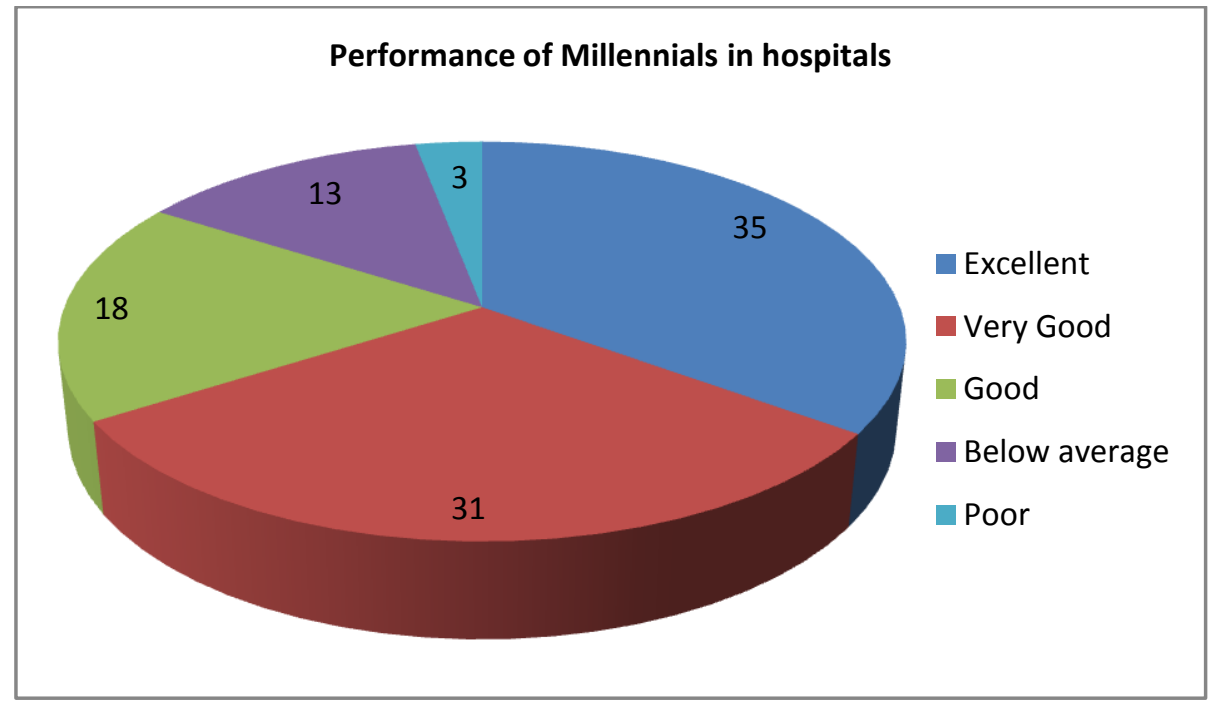

Source (Author, 2017) 
The above Figure shows that the highest percentage is of those who rated their performance as Excellent (35\%), followed by Very Good (32\%), Good had 18\% while 13\% rated themselves as Below Average. Only 3\% rated themselves as Poor.Given that thisitem was a self-assessment or self-evaluation question, the results indicated above should be treated with care because most workers tend to over-rate and over-value their performance. The above results contradict press reports which state that there is poor service delivery in hospitals and they also contradict the findings of Kamau et.al (2014), who found out that Millennials have very high rate of absenteeism and frequently reported late for duty. However, notwithstanding possibilities of biased self-rating or over-rating, it was envisaged that since these health employees hold human life in their hands, their performance should always be excellent at all times because giving any room for poor performance would lead to loss of life.

\subsubsection{Employee attitude towards work}

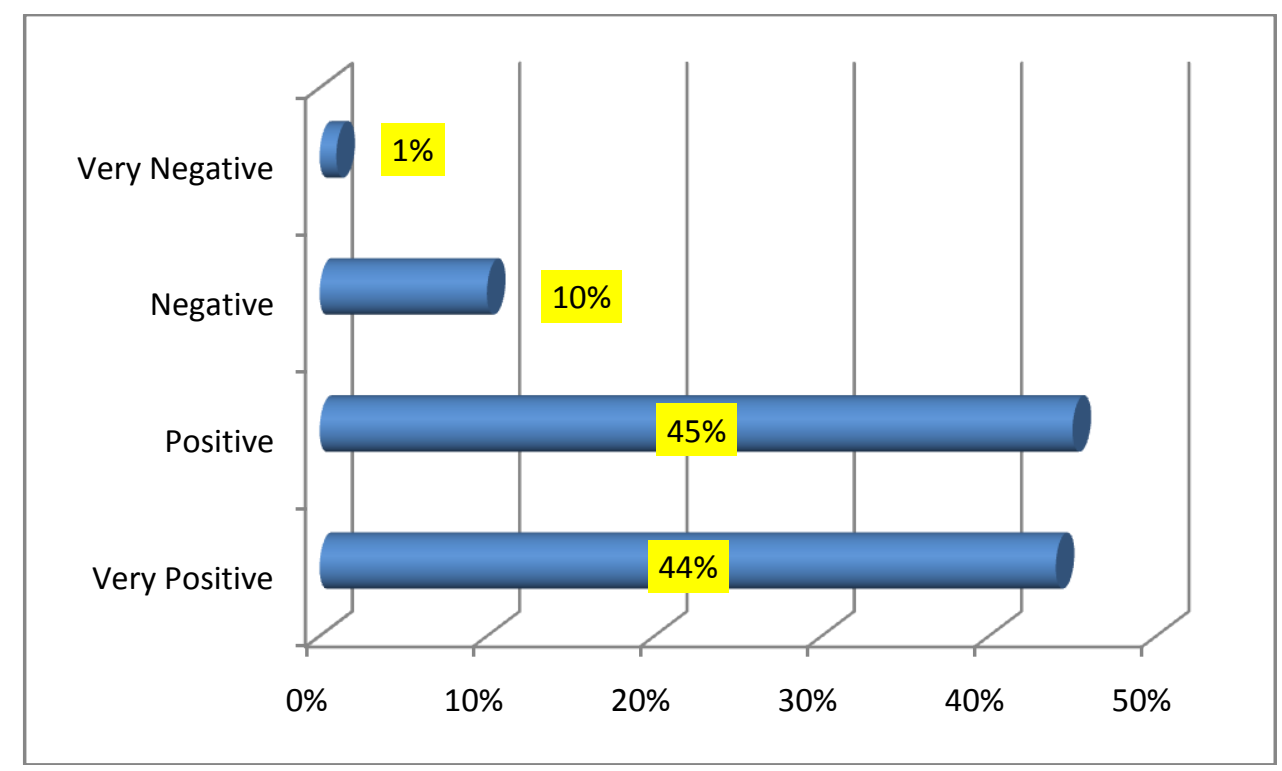

Source (Author, 2017)

According to the information gathered, the Figure above shows that $44 \%$ and $45 \%$ of the respondents rated their attitudes towards work as very positive and positive respectively. Only $10 \%$ and $1 \%$ rated themselves asnegative and very negative. While this was again a case of self-assessment or self-evaluation which should be treated with care, the findings agree with the findings of Gursoy et.al, (2008) who state that this Generation Y employees are perceived to be more cooperative and optimistic. However, Kamau et.al (2014) postulates that Generation Y employees have a different attitude towards work as compared to other previous generations.

\subsection{Factors affecting the performance of Millennials}

The statistics outlined in the table below show the responses on the motivators or preferences for Millennialson a scale of 1 to 5 .

1= Strongly Disagree $(\mathrm{SD}), \mathbf{2}=$ Disagree $(\mathrm{D}), \mathbf{3}=$ Neutral $(\mathrm{N}), \mathbf{4}=$ Agree $(\mathrm{A}), \mathbf{5}=$ Strongly Agree $(\mathrm{SA})$

Factors Affecting the Performance of Millennials

\begin{tabular}{|c|c|c|c|c|c|c|}
\hline Item & Factor & $\begin{array}{l}\text { SD } \\
1 \\
\end{array}$ & $\begin{array}{l}\mathrm{D} \\
2 \\
\end{array}$ & $\begin{array}{l}\mathrm{N} \\
3 \\
\end{array}$ & $\begin{array}{l}\text { A } \\
4\end{array}$ & $\begin{array}{l}\text { SA } \\
5\end{array}$ \\
\hline B1 & I prefer to be deployed to a hospital close to family and friends. & 2 & 16 & 25 & 33 & 24 \\
\hline B2 & $\begin{array}{l}\text { I prefer to be deployed to a hospital where accommodation is available and } \\
\text { affordable. }\end{array}$ & 5 & 11 & 28 & 29 & 27 \\
\hline B3 & $\begin{array}{l}\text { I prefer to be deployed to a hospital where transport to and from work is readily } \\
\text { available and affordable. }\end{array}$ & 2 & 6 & 32 & 34 & 26 \\
\hline B4 & I joined the health profession out of choice and passion to serve. & 41 & 18 & 13 & 16 & 12 \\
\hline B5 & I prefer to work where there is adequate equipment and modern technology. & 0 & 1 & 12 & 44 & 43 \\
\hline B6 & I prefer to work flexible hours. & 0 & 0 & 3 & 21 & 76 \\
\hline B7 & I prefer working in teams in a friendly working environment. & 1 & 0 & 4 & 13 & 82 \\
\hline B8 & I prefer a challenging work environment. & 3 & 5 & 7 & 18 & 67 \\
\hline B9 & I prefer a work place with opportunities for advancement. & 0 & 0 & 1 & 18 & 81 \\
\hline B10 & I prefer to get decent and fair remuneration. & 1 & 3 & 6 & 9 & 81 \\
\hline
\end{tabular}


An Investigation of Factors Affecting Employee Performance among Millennials in the Public...

\begin{tabular}{|c|c|c|c|c|c|c|}
\hline B11 & I prefer to get recognition and positive feedback for good work done. & 0 & 0 & 8 & 18 & 74 \\
\hline B12 & I prefer a workplace with continuous training and staff development. & 0 & 0 & 6 & 19 & 74 \\
\hline B13 & I prefer to get holiday entitlement. & 1 & 0 & 6 & 17 & 76 \\
\hline B14 & I prefer to work in teams. & 0 & 1 & 2 & 18 & 79 \\
\hline B15 & I prefer to on contributions. & 0 & 1 & 0 & 14 & 85 \\
\hline
\end{tabular}

(Source: Author, 2017)

\subsubsection{Deployment to hospitals close to family and friends}

From the responses shown above $18 \%$ of participants disagreed with the notion that they prefer deployment to a hospitals close to family and friends, $25 \%$ were neutral and $57 \%$ agreed. This agrees to the findings of the study carried out by Robert Half International (2008) that Millennialswould stay longer if they are offered perks and programs that help them achieve work/life balance.The results show that the majority of Generation Y employees prefer to stay close to family and friends as the greater number of these employees are usually still staying with parents or have just started a married life resulting in it being difficult for them to want to work away from family and friends.

\subsubsection{Deployment to hospitals where accommodation is accessible and affordable}

Seventy six percent of the respondents agreed that they prefer deployment to hospitals where accommodation is available and affordable. According to Maslow'sHierarchy of Needs Theory (1954)as cited in Leonard et al.(1999), shelter is a basic need. It is natural that any employee will consider the availability of accommodation before taking up employment. Management's attitude as realized from their responses to the interviews conducted showed a "take it or leave it" attitude as one manager said; "There are many qualified people out there who are seeking employment. We have shortage of accommodation and if one is choosy, he/she is free to go and we give the work to the next person". Such attitudes of management does not help the situation as hospitals will continue to have disgruntled staff and high staff turnover will persist.

\subsubsection{Deployment to hospitals where transport is available and affordable}

The majority of young employees prefer to work where there is good transport network as shown by $86 \%$ of the respondents who responded as such while 14\% disagreed. Losky (1997) indicates thatMillennials are heavy consumers of entertainment and most entertainment is in towns and cities. Given that Zvimba District is largely rural, the availability of transport to urban centres for entertainment, shopping etc. becomes a major issue.

\subsubsection{Joining the profession by choice}

The findings show that $69 \%$ of the respondents disagreed to the assertion that they joined the profession by choice; $13 \%$ remained neutral and $18 \%$ agreed. Health professionals are care givers who deal with patients. It would have been most appropriate that those who join the health profession do so out of choice and out of passion. The findings are a major area of concern where a majority of respondents among health workers implied that they were forced by circumstances to work in hospitals. Such employees are not expected to give their best and it puts a lot of strain on hospital management who have to deviseextra-ordinary motivational techniques to inspire such workers to perform at best since using force would achieve negative results given that in hospitals, human life is at stake. The responses are supported by the fact that most industries in Zimbabwe collapsed due the economic meltdown of the decade up to 2008 leaving the Public Service (Government) as the main employer. This left Millennialswith limited career choices with many ending up as nurses, doctors or paramedics.

\subsubsection{Availability of adequate equipment and modern technology}

From the table above, it is clear that the majority of the participants (87\%) agreed that they prefer a work environment with adequate equipment and modern technology, $12 \%$ were neutral and only $1 \%$ percent disagreed.Reeves and Oh (2007), states that Generation Y have an innate (in-born) ability to use technology and are comfortable with multitasking by using a diverse range of digital media. Technology helps make tasks easier and faster enabling shorter and flexible working hours.

\subsubsection{Preference of flexible working hours}

The majorityof respondents constituting $97 \%$ prefer to work in organizations where there are flexible working hours, and only $3 \%$ were neutral. This finding agrees with the statement by Miller, Hodge \& Brandt (2013) in Jerome et.al. (2014), who state that Generation Y seek flexibility and if granted,that can motivate them to perform better. 
An Investigation of Factors Affecting Employee Performance among Millennials in the Public...

\subsubsection{Preference of a friendly work environment}

According to the analysis, $95 \%$ of the respondentspreferred a friendly working environment, $4 \%$ were neutral and 1\% disagreed. The results concur with the findings of Miller, Hodge \& Brandt (2013) in Jerome et.al. (2014), who state that Millennialswant a relaxed dress codes, friendly management and to work among friends.

\subsubsection{Preference of a challenging workingenvironment}

The sum of $85 \%$ overwhelmingly responded positively to the assertion that they prefer a challenging working environment, $7 \%$ being neutral and $8 \%$ not in agreement. Hastings, (2009) postulates that Generation Y employees' performance can be increased by way of challenging daily tasks.

\subsubsection{Preference of opportunities for advancement}

It was the finding of this study that the majority constituting $92 \%$ of the respondents agreed that they prefer to work where they are allowed career advancement opportunities, 7\% disagreed. Erickson (2008) in Brown et.al found out that Millennials expect to climb the career ladder faster despite lack of experience and at a rate considered to be unreasonable by co-workers from other generations. Hastings (2009) also stated that Generation Y requires continuing education thus agreeing to the preferences of the respondents.

\subsubsection{Decent salary and remuneration}

An analysis of the data presented shows that $96 \%$ of the respondents prefer decent and fair remuneration, $4 \%$ disagreed. Contrary to the results, studies by Whitley, (2002) have shown that money does not improve performance. Herzberg's Two Factor Theory of motivation also contradicts this finding when it states that salary is not a motivator, it is just a hygienic or maintenance factor. Notwithstanding that a theory is a proven truth, given the responses, one can conclude with certainty that in Zimbabwe, Civil Servants in the health sector treat salary as a motivator and absence of a decent salary affects performance.

\subsubsection{Recognition for good work done}

According to the findings, $92 \%$ of the respondents agreed that they prefer to be recognised for good work done and $8 \%$ disagreed. William (2010) states that for a lot of people, the feeling of being recognised and valued appears more important than money.

\subsubsection{Preference of continuing training and development of staff}

Ninety four percent of the respondents prefer a workplace with continuous training and development of staff and $6 \%$ were neutral. Robert Half International (2008) noted that perks such as education, training and advancement opportunities do not only help the organisation to attract and retain professionals but also help position workers to tackle new business challenges.

\subsection{Leadership Styles Appropriate for Millennials}

Authorities in leadership among them Sharma (2013), Shoemaker (2012) and Mendoza (2013) agree that there is nothing like one leadership style for an organization. These scholars in leadership concur that leaders use Contingency leadership style which is really situational in that the leader does not rely on one style, but he/she changes the leadership style to fit the situation at hand. However, in practice, there is usually a dominant leadership style which a leader uses in line with his/her personality and training. This section sought to find out the dominant leadership styles used to lead Millennials in hospitals and what the Millennials themselves prefer. The table below shows the distribution of responses on Generation Y's perceptions on leadership styles used in hospitals on a scale of 1 to 5 representing strongly disagree, disagree, neutral, agree and strongly agree respectively.

Leadership Styles used on Generation Y in hospitals

1=Strongly Disagree (SD); 2=Disagree(D); 3=Neutral(N); 4=Agree(A); 5= Strongly Agree (SA)

\begin{tabular}{|c|c|c|c|c|c|}
\hline & \multicolumn{5}{|c|}{$\%$ Frequency } \\
\hline & $\begin{array}{l}\text { SD } \\
1\end{array}$ & $\begin{array}{l}\mathrm{D} \\
2\end{array}$ & $\begin{array}{l}\mathrm{N} \\
3\end{array}$ & $\begin{array}{l}\text { A } \\
4\end{array}$ & SA5 \\
\hline Q1. The leadership uses force - the 'do as I say' thing. (Autocratic) & 13 & 5 & 24 & 43 & 15 \\
\hline Q2. I prefer my leaders at work to use autocratic style in leading us & 45 & 40 & 10 & 4 & 1 \\
\hline Q3 The leadership at my workplace uses the Laissez-faire style (We do as we wish) & 48 & 33 & 10 & 5 & 4 \\
\hline Q4. I prefer that my leaders at work use the Laissez- faire style in leading us & 12 & 15 & 11 & 29 & 33 \\
\hline $\begin{array}{l}\text { Q5. The leadership consults and allows decisions to be made in teams. (Consultative/ } \\
\text { Participatory leadership) }\end{array}$ & 41 & 34 & 13 & 8 & 4 \\
\hline Q6. I prefer that my leaders at work use Consultative/ Participatory style as one of the styles & 8 & 10 & 9 & 34 & 39 \\
\hline
\end{tabular}


An Investigation of Factors Affecting Employee Performance among Millennials in the Public...

\begin{tabular}{|c|c|c|c|c|c|}
\hline in leading us & & & & & \\
\hline $\begin{array}{l}\text { Q7. Leadership at my work affords me equal opportunity to give input in decision-making. } \\
\text { It is leadership for the people, by the people (Democratic) }\end{array}$ & 33 & 37 & 19 & 9 & 2 \\
\hline Q8. I prefer that my leaders at work use Democratic Style as one of the styles in leading us & 5 & 7 & 5 & 36 & 47 \\
\hline $\begin{array}{l}\text { Q10. I prefer that my leaders at work use Transactional leadership style as one of the styles } \\
\text { in leading us }\end{array}$ & 15 & 16 & 19 & 24 & 26 \\
\hline $\begin{array}{l}\text { Q12. I prefer that my leaders at work use Servant Leadership as one of the styles in leading } \\
\text { us }\end{array}$ & 10 & 9 & 8 & 29 & 44 \\
\hline $\begin{array}{l}\text { Q13. The leadership helps subordinates perform at their best. They really inspire us to enjoy } \\
\text { work (Inspirational Leadership) }\end{array}$ & 18 & 39 & 19 & 19 & 5 \\
\hline $\begin{array}{l}\text { Q14. I prefer that my leaders at work use Inspirational Leadership as one of the styles in } \\
\text { leading us }\end{array}$ & 9 & 11 & 11 & 35 & 34 \\
\hline
\end{tabular}

(Source: Author, 2017)

\subsubsection{Autocratic Leadership}

The data presented on the above table clearly points to the fact that a majority of respondents who constitute 58\% agree that leadership in hospitals are autocratic. This means the leadership uses force with a "do as I say" attitude; $18 \%$ did not agree and a large number constituting $24 \%$ opted to remain neutral. As alluded to by Iqbal et.al (2015), autocratic leadership undermines the ability and input of others. In response to the next question, a majority of respondents constituting $85 \%$ stated that they do not prefer autocracy, $10 \%$ were neutral and only 5\% were in favour. The findings show that the leadership style practiced by management in hospitals was at variance with what Millennials preferred. In earlier responses, Millennialshad indicated that they are motivated by a friendly working environment and autocracy does not create a friendly working environment. This affects the performance of Millennials and management should improve on this aspect by doing away with dictatorial practices.

\subsubsection{Laissez-faire}

Responses show that $81 \%$ of the respondents disagreed that their management uses the laissez-faire leadership style, $10 \%$ were neutral and 9 percent were in agreement. Given the nature of policies, regulations, procedures and operations in the Public Service in Zimbabwe indeed the laissez-faire style where employees do what they want as if there is no leader is not possible. However, $62 \%$ of the respondents preferred to do what they want, $11 \%$ were neutral and $17 \%$ rejected laissez-faire. This shows that Millennials prefer to be given freedom. While this is not possible at a workplace, there was need to balance their preference by allowing them to be free on certain aspects of their job which does not bring patients' lives into danger.

\subsubsection{Participatory/ Consultative Leadership}

The findings show that $75 \%$ of the respondents, constituting the majority, disagree that their leaders use Participatory/ Consultative Leadership style, $13 \%$ were neutral and 12\% agreed. Iqbal et.al (2015) propounded the "I share" philosophy whereby decisions are made in team with each member having equal opportunity to give his/her input. Based on the results from the respondents, Participatory or Consultative leadership style is not being exercised in institutions under study and that is bound to demoralize and demotivate Millennials $73 \%$ of whom preferredtheParticipatory style. The responses show that there is a variance between what is practiced in hospitals and what Millennials prefer.

\subsubsection{Democratic Leadership}

The majority of respondents (70\%) indicated that their leadership was not democratic, only $11 \%$ agreed and 19\% remained neutral concerning the matter. Podsakoff, MacKenzie, Moorman and Fetter (1990) expanded upon Burns (1978)'s ideas and stated that democratic leaders make their subordinates feel that they are part of the organization and this helps them to do more than expected. The absence of democracy in hospitals may affect the performance of Millennials and hospital management should endeavour to improve on this aspect. While respondents indicated that their leaders do not practice democracy, $82 \%$ stated that they preferred leaders who use democracy. Again there is a variance between reality and the preference of Millennials. This bound to affect performance. 
An Investigation of Factors Affecting Employee Performance among Millennials in the Public...

\subsubsection{Transactional Leadership}

As presented on the table above,54\% of the respondents disagree that management uses transactional leadership.Eighteen percent were neutral and 9\% were in agreement. Yukl (2006) sates that transactional leaders offer inducements to make employees move in the direction desired by the leaders as a give and take strategy. In response to question Q10, 50\% of the respondents preferred Transactional leadership, 19\% were neutral and $31 \%$ rejected it.

\subsubsection{Servant Leadership}

The data presented on the table shows that $56 \%$ of the respondents disagreed to the assertion that servant leadership style is practiced in their workplaces. Given that servant leadership prioritises the needs of employees, it can be concluded that management in hospitals do not adequately care about the needs of Millennials. Eighteen percent were neutral and 26\% were in agreement. According to Greenleaf (1970) as cited in Smith (2005) "A great leader is seen as servant first..." In response to question Q12, 735 of the respondents indicated that they prefer Servant leadership, $8 \%$ were neutral and 19\% rejected it. Analysis shows that while management in hospitals were not practicing servant leadership, a majority of Millennials prefer it as it puts their interests ahead of anything else.

\subsubsection{Inspirational Leadership}

The table shows that $57 \%$ of the participants disagreed that their leaders are inspirational, $19 \%$ were neutral and 24\% agreed. The findings contradict with Greenleaf as cited by Spears (2005) who states that it is the sole role of managers to inspire employees to perform to the best of their ability because there is no worker who is lazy without cause. Of the 100 respondents 69 stated that they prefer to be led by leaders who practice inspirational leadership while $11 \%$ remained neutral with $19 \%$ rejecting it. Again this is a case were the leadership style used in hospitals is at variance with what Millennials prefer.

\subsubsection{Transformational Leadership}

Eighty-one percent of the respondents disagreed that their leadership is transformational. In other words, they implied that their leadership does not welcome change and will stick to routine. Such leadership will not take personal risks and sacrifices nor encourage others to do so to achieve organizational goals, $6 \%$ agreed and 13\% were neutral. According to Devinney, (2009), a transformational leader tries to be actively involved and he/she is a shaker and a mover who allows for change and innovation. Given the responses, it can be concluded that Millennials in hospitals are not motivated. In response to question Q16, a majority constituting $80 \%$ indicated that they prefer transformational leaders yet leaders in hospitals were not practicing it. Such variance is likely to affect the performance of Millennials.

\subsection{Hypothesis Testing}

While the above table indicated that the leadership styles used by management in hospitals were at variance with what Millennials expected thereby breeding fertile ground for disgruntlement, demotivation and poor performance, there was still need to use more powerful tests like the Binary Logistic regression to test the hypothesis below on leadership style to ascertain if it affected the performance of Millennials:

$\mathbf{H}_{\mathbf{0}}$ : $\quad$ The performance of Generation $\mathrm{Y}$ in the Public Service in Zimbabwe is not significantly associated with leadership style used by their managers.

$\mathbf{H}_{1}$ : $\quad$ The performance of Generation Y inthe Public Service in Zimbabwe is significantly associated with leadership style used by their managers.

The table below shows the regression coefficients computation results:

\section{Regression coefficients}

\begin{tabular}{|l|l|l|l|l|l|l|l|}
\hline \multicolumn{2}{|l|}{ Variables in the Equation } & B & S.E. & Wald & df & Sig. & Exp(B) \\
\hline \multirow{4}{*}{ Step 1 ${ }^{\text {a }}$} & Autocratic(1) & -.238 & .582 & .167 & 1 & .683 & .788 \\
\cline { 2 - 8 } & Consultative/ Participatory & .724 & .613 & 1.392 & 1 & .238 & 2.062 \\
\cline { 2 - 8 } & Democratic(1) & -.670 & .694 & .932 & 1 & .334 & .512 \\
\cline { 2 - 9 } & Transactional(1) & .631 & .640 & .971 & 1 & .324 & 1.879 \\
\cline { 2 - 9 } & Servant(1) & .292 & .433 & .457 & 1 & .499 & 1.340 \\
& Inspirational & .292 & .433 & .457 & 1 & .499 & 1.340 \\
\hline
\end{tabular}

\section{Source: SPSS Output}

It can be seen from the results on the table above that the regression equation as given by: $\mathbf{Y}=\mathbf{0 . 6 9 3}$ a constant, where $\mathrm{Y}$ is a function of Generation Y's performance implies that the performance of Generation $\mathrm{Y}$ in 
Zimbabwe is independent of leadership style. The unemployment rate in Zimbabwe is high and competition for jobs is tense, so employees will try their best to make their superiors happy. It does not matter the leadership style used by management and how badly employees are treated, workers will fight to keep their job in order to have the next meal on the table while quietly searching for earliest opportunities to leave for greener pastures.

\section{Conclusions}

The study sought to investigate the factors affecting the performance of Millennials(employees aged between 22 and 36 years)in the Public Service of Zimbabwe and health employees in Zvimba District were the focal point. The study concluded that several factors motivate Millennials to work hard and these include being deployed to hospitals close to family and friends, where there is adequate equipment and modern technology.They are motivated by being deployed where there are no transport problems and where accommodation is readily available. It was also concluded that Millennials are motivated by working flexible hours in a friendly working environment. They also enjoy challenging work with opportunities for selfadvancement. Millennials are motivated by decent and fair remuneration and they desire to be recognised for good work. Millennials enjoy working in teams in a dynamic environment which welcomed change and they want their contributions in the workplace to be considered through positive feedback.

The study concluded that Millennials appreciate democratic leadership, servant leadership, transformational leadership, transactional leadership, laissez-faire and consultative or participatory leadership styles. It was concluded in this study that management in hospitals was not practising these leadership styles well. The findings of the study led to the conclusion that management in hospitals were too bureaucratic and they tended to use autocratic leadership styles which were not appreciated by Millennials. The study noted that due to the macro-economic environment where many health professionals are unemployed, management were not eager to go an extra mile to motivate and be persuasive to Millennials. They employed the 'take it or leave it' attitude where they are not bothered when Millennials resign because when they leave it was easy to recruit from the rank and file of the unemployed. This demoralised most Millennials who habour interests to resign and leave their work stations once opportunities arose. Management also feels that there is little they can do to address the problems of the Millennialssuch as desire for a decent salary.

The study also concluded that while Millennials were demotivated and while they endured bad leadership styles, they had little choice given the harsh economic situation in Zimbabwe characterised by high unemployment levels.

\section{Recommendations}

After literature search, data collection and data analysis, this study came up with the following recommendations for consideration in the management of Generation $\mathrm{Y}$ employees in the health sector:

\subsection{Recommendations to the management of Generation Y employees in Hospitals}

6.1.1 Management in hospitals should seek to understand the problems, career expectations, behaviours, work habits, life goals, attitudesand wishes of Millennials and actively work towards addressing their problems. Basic needs such as accommodation, transport, communication channels including availability of internet should be prioritised.

6.1.2 Hospital management should use modern leadership techniques and should shun autocratic leadership styles.

6.1.3 Where managers of Millennials are unable to assist on some of the issues which are beyond their purview, they should communicate with Millennialsand pass on the concerns to the appropriate offices rather than ignoring them because in the end, it is patients who suffer from poor service delivery from disgruntled health workers.

6.1.4 Managers should recognise best performers and create incentives such as Worker of the Month/Year Award. This will encourage other workers to thrive to perform better.

6.1.5 Management in hospitals should create challenging and friendly working environment in order to enhance creativity of employees.

6.1.6 Management should lobby Government and the donor community to review conditions of service of health employees especially remuneration. Targeting average regional salary scales couldhelp reduce brain drain and migration to neighbouring countries.

6.1.7 Hospital management should prioritise team building since health work requires team effort. 
6.2 Recommendations to policy and to the employers of Generation Y employees in hospitals (Public Service Commission/ Government)

6.2.1 There is need for deliberate training programmes for all leadership in hospitals on howto handle the new generation of workers given that Millennialsare significantly different from other classes of workers which managers are used to.

6.2.2 Given the fact that human life comes first, remuneration of health employees should be reviewed upwards so that they can be happy to provide the best service to patients.

6.2.3 Disgruntled demotivated managers cannot be expected to motivate their demotivated subordinates as they are most likely to infect their disgruntlement to their juniors. This calls for the remuneration of managers/ leadership in hospitals to be reviewed too.

6.2.4 Psychometric tests should be used during interviews to make sure that only those with a correct aptitude train as health workers in colleges and universities. Simply requiring passes at O' level or A' level as entry requirement may not work for the health sector. The current situation where people join the health profession against their wish but simply because they have no other option is not helping the situation as some Millennials in hospitals really hate their jobs.

6.2.5 There is need to address the issue of staff shortage as caused by recruitment freeze in hospitals in order to address the issue of flexible working hours.

6.2.6 Authorities should mobilise resources such as proper infrastructure including internet, furniture, modern technology, accommodation and transport among other needs.

\subsection{Recommendations for further studies}

This study concerned itself on investigating the factors that affect the performance of Millennials (Generation Y)inin the Public Service with specific focus on health employees in Zvimba District, Zimbabwe which covered six hospitals. Further research covering other districts in other provinces would make interesting comparison especially when such study is carried out to separate Millennials who work in rural hospitals and those who work in urban hospitals. A study which investigates the skills possessed by the managers in the health sector would also make interesting reading as the lack of skills by managers might be fuelling brain-drain and could be responsible for causing Millennials to fail to perform to expectations. Longitudinal and tracer studies which trace the work ethics, work attitudes and behaviours of Millennials as they grow older would equally make interesting reading to find out whether Millennialscontinue to be techno-savvy in older age even as they approach retirement or such interests would wane out as they grow older.

\section{References}

[1]. Brown, M. E. and Trevino, L. K. (2006). Ethical Leadership: A Review and Future Directions. The Leadership Quarterly, (17), 596616.

[2]. Bryman, A. (2006), "Integrating quantitative and qualitative research: how is it done?", Qualitative Research, Vol. 6 No. 1, pp. $97-$ 113.

[3]. Dench, S.,Iphofen.R. and Huws.U.,2004.An EU Code of Ethics for SocialResearch.Brighton(UK).Institute of Employment Studies Report 412. onlinewww.respectproject.org

[4]. Denham, T.J. (2002) A Course Paper Presented To Programmes For Higher Education in Partial Fulfilment of the requirements for the degree of Doctor of Education. Nova South Eastern University.

[5]. Dench, S., Iphofen, R. and Huws, U. (2004) IES Report 412. AnEU Code of Ethics for Socio-economic research. Brighton, UK: The Institute of Employment Studies.

[6]. Greener, S (2008) Business Research Methods.Bookboon.

[7]. Greenleaf, R.K (1970) The Servant As Leader. Indianapolis, IN: Greenleaf Centre.

[8]. Grit, K. (2004). Corporate citizenship: How to strengthen the social responsibility of managers? Journal of Business Ethics, 53(12), 97-106.

[9]. Iqbal, N., Anwar, S. and Haider, N. (2015), Effect of Leadership Style on Employee Performance: Arabian J Bus Manag Review 5: 146.

[10]. Keep, E. and Westwood, A. (2003) Can theUK learn to manage? The WorkFoundation.

[11]. Kian, T.S., and Yusoff, W.F. (2012) Generation X and Y and Their Work Motivation.Proceedings International Conference of Technology Management, Business and Entrepreneurship in Malaysia.396-408.

[12]. Kogan, M. (2001).Bridging the Gap: Government Executive Human Resource Management Magazine.Retrieved from http://www.govexec.com/magazine-human -resource- management/2001/09/bridging-the gap/97529.

[13]. Lancaster, L.C. and Stillman, D.(2002) When Generations Collide: Who They Are, why they clash, How To Solve The Generational Puzzle at Work. New York: Harper Collins Publishers .Inc

[14]. Leavitt, R. (2014), Generation Differences in Work Motivation of Healthcare Workers: University of Nebraska-Lincoln.

[15]. Leonard.N.H.,Beauvois, L.L., and Scholl, K.W.(1999). Work Motivation: The Incorporation of Self Concept- Based Processes. Human Relations, 52(8), 969-998.

[16]. Maslow, A (1954) Motivation and Personality. New York : Harper and Rowe.

[17]. Porter, L. W., Bigley, G.A., and Steers, R.M (2003) Motivation and Work Behaviour. Boston, MA: McGravaHillrumin.

[18]. Reeves, T. C., and Oh, E. (2008). Generational Differences in Spector, M.J., Merill, M.D., Merrienboer, J.V. and Discroll, M.P.,(eds), Handbook of Research on Education, Communications and Technology $3^{\text {rd }}$ edition, pp. 298-303.

[19]. Saunders, N.K., Thornhill, A., Lewis, P (2009) Research Methods For Business Students. $5^{\text {th }}$ edition. Paperback: Pearson.

[20]. Smith, C. (2005) Servant Leadership: The Leadership Theory of Robert K Greenleaf, UK.

[21]. Spears, L C (2005), The Understanding and Practice of Servant Leadership, School of Leadership Studies, Regent University 
An Investigation of Factors Affecting Employee Performance among Millennials in the Public...

[22]. Spears, L.C (2010), Character and Servant Leadership. School of Global Leadership and Entrepreneurship, Regent University.

[23]. Yukl, G. (2006). Leadership in Organizations(6th ed.). Upper Saddle River, NJ: Pearson-Prentice Hall.

[24]. Yukl, G (199) An Evaluation of Conceptual Weaknesses in Transformational AND Charismatic Leadership. The Leadership Quarterly. 10(2), 285-304.

[25]. http://seanlyons.ca/wp-content/uploads/2012/01/Leadership-Preferences-of-Gen-Y.pdf

[26]. http://file.scirp.org/pdf/OJBM_2013070511522943.pdf

[27]. http://eprints.uthm.edu.my/3431/1/MGT071.pdf 